\title{
Imitating Democracy and Populism as an Attribute of Modern World Countries
}

\author{
Mariia Pryziglei \\ Ph.D. in Political Science, Presidium of National Academy of Sciences of Ukraine \\ (Kyiv, Ukraine) \\ E-mail: m.pryziglei@gmail.com \\ https://orcid.org/0000-0002-3449-8412
}

Pryziglei, Mariia (2019) Imitating Democracy and Populism as an Attribute of Modern World Countries. Ukrainian Policymaker, Volume 5, 77-88. https://doi.org/10.29202/up/5/9

Spreading of imitation democracy and populism as the attributes of modern world countries are analyzed in the article. It is established that a totalitarian-democratic society, as a rule, is characterized by illusory economic prosperity, multicultural diversity of customs and traditions, free access to information and dissemination, many freedoms and conveniences. All this illusion is actively supported by the government and the media, which in such societies are directly controlled by the state or belonging to groups loyal to power and serve as a tool for balancing and counteracting antagonistic movements. It is revealed that the totalitarian-democratic regime seeks to integrate any opposition and absorb possible alternatives to the development of the state. That is, on the one hand, the establishment of imitative democracy proclaims the state democratic, formally enshrining all the principles of a democratic society, and on the other, insulates civil society from participation in the formation and exercise of public authority. In addition, totalitarian democracy does not seek to resolve social contradictions, but obscures them with a screen with false symbols and values.

It has been found that since the activities of antagonistic movements in totalitarian democracies are not a threat to their existence, critically-minded activists are generally not persecuted or even encouraged. The government seeks to create the conditions under which any criticism becomes trivial and routine and, accordingly, imperceptible to most of society.

The proposals on the necessary actions for overcoming the "challenge" of populism and minimizing the risks of spreading the regime of imitative democracy in the world are highlighted, in particular: mobilization of civil society in support of democratic institutions; strengthening the rationalization and institutionalization of the political process; political isolation of populists through the formation of large centrist coalitions in parliaments; more active involvement of citizens in the democratic process of decision-making; formulating an attractive program agenda; attracting new people to centrist parties.

Keywords: political regime, liberal democracy, imitative democracy, populism, anti-liberal political movements

Received: December 2, 2019; accepted: December 11, 2019

(C) Pryziglei, Mariia, 2019 


\section{Introduction}

Researchers on the problems of theory and practice of democracy in today's world emphasize the imitative nature of democracy in transitional states. However, a similar situation is also typical of countries with longer traditions of democratic rule. Some researchers even conclude that imitative democracy is now becoming the most widespread form of political regime in the world.

Today, western democracies are faced with the two types of difficulties: 1) strengthening the role of authoritarian forces in Russia, Iran, Turkey, which stop the movement to democracy and oppose themselves to the liberal West, professing the concept of autonomous modernization (in fact it is a global competition between authoritarianism and democracy); 2) an anti-liberal movement within European countries and the United States (the Trump presidency, Brexit, intensifying right-wing populist and right-wing extremist movements), which weakens the solidarity of Western countries in the face of challenges and threats from authoritarian states.

The greatest threat to democracy is populism, which has become at the heart of the antidemocratic movement. Today, populist parties are present in the parliaments of eight European Union countries, three - in Hungary, Poland and Italy — are parties in power. In addition, this trend is upward. The classic Liberal Democratic parties do not have time to adapt to the new communication and organizational challenges, and thus lose to the populists.

Partly spreading of populism in the EU is facilitated by the media, which, instead of meaningful facts and meanings, very often relay emotions, post-truths and even fakes to society.

\section{Theoretical Background}

There are usually no pure forms of political regime. Authoritarian and totalitarian governments may be characterized by certain democratic attributes, and conversely, democracy may use certain non-democratic practices.

The classic approach to a clear demarcation of democratic and totalitarian political regimes today requires a revision, as new forms and methods of governing society emerge as the information society develops. Undoubtedly, stable elements of classical totalitarianism are inherent in some modern states of the world, such as North Korea. But political regimes of a latently totalitarian character, dubbed totalitarian (imitative, governed, manipulative, decorated, front) democracy, are becoming more widespread. Concepts of quasi-democracy and pseudodemocracyare also used to refer to this type of political power organization.

J.L. Talmon was the first who formulate the concept of totalitarian democracy in 1952 (Talmon, 1961). This issue has also been learning by U. Engdahl(Engdahl, 2010), D. Furman, who, however, uses the term "imitation democracy"(Furman, 2007), V. Pribylovsky, who uses the term "managed democracy"(Pribylovsky, 2005), and others.

A. Kalinina defines totalitarian democracy as (Kalinina, 2014: 283) a form of political regime in which democratic legislation is formally enforced and all electoral rules and procedures are observed, while civil society participation in government and the influence of society on power are in fact is minimum or absent. That is, the main distinguishing feature of imitative democracy is the removal of civil society from real governance and the absence (or minimum level) of its influence on the state public policy. At the same time, the combination of totalitarian democracy with elements of representative democracy is real (Talmon, 1993: 191-214; Kalinina, 2014: 284). 
The main characteristics of imitative democracy are:

1. Electoral formalism, the formal nature of the principle of universal suffrage, formal and factual qualifications for active and passive suffrage.

2. Elitism and caste, lack of "social lifting" in the society that really reflects the ability of the political system to update and embrace progressive ideas.

3. Absence of real political and economic competition, political competitiveness.

4. Concentration and manipulation of important public resources in the hands of a limited number of individuals for exceptional benefits.

5. Low representation of different social groups in public authorities and low reflection of their interests in public decisions of these bodies.

6. The poor legitimacy of power in the people's eyes.

7. Practical sensibility of citizen participation in political processes other than elections.

8. Use of extra-legal instruments.

9. Lack of clear political identity in political parties.

10. Total corruption of the bureaucracy.

11. Removal of the political party from the people, inefficiency of the state mechanism and general dysfunctionality of the state.

\section{Research results}

In general, the imitation democracy regime is widespread in the late $20^{\text {th }}$ and early $21^{\text {st }}$ centuries, in particular: much of Asia, almost all of Africa, and in the past - Latin America, most of the Arab states, are imitation, governed, or totalitarian democracies. Modern examples of totalitarian democracies include the Russian Federation with "adapted democracy" by Vladimir Putin, Belarus "with the free choice of Aleksandr Lukashenko", and Kazakhstan with the regime of Nursultan Nazarbayev. Ukraine also has signs of imitative democracy.

What is the main reason for the establishment of a totalitarian democracy in the post-Soviet states? According to D. Furman, the starting point for the establishment of democracy in these countries was the proclamation of such principles as democracy, building a market economy, ensuring human and citizen rights, the movement to Europe and progress. However, in all these states there was virtually no psychological and cultural ground to accomplish the tasks. And most importantly, no one was involved in the creation of such soil. Moreover, in most states that were part of the USSR, there was not the least democratic experience necessary to exist in modern conditions (except for the Baltic countries), and some countries did not have the experience of an independent state. That is, a number of problems have fallen on these states - the simultaneous transition to both a new social order and a new political order, the creation and construction of a new, first nation-state of its own (Furman, 2007).

The reasons and prerequisites for the emergence of a state of imitative democracy include:

a) the awareness by the ruling circles of the renewed state the need for active external attributive demonstration to new foreign partners of the commitment adopted in the systems of the last benchmarks in order to prevent the application of sanctions and political isolation;

b) the distorted consciousness of person and society in general, which were formed primarily under the influence of historical cultural and spiritual heritage. 
Means of combating imitative democracy and ways of overcoming its negative impact on the state of democracy are:

a) expanding the boundaries of human consciousness, critical thinking;

b) dissemination of true and deep knowledge of the essence of the political and legal phenomena of the present;

c) consistent disclosure of defects in functioning social systems.

The key to democracy as a political good of social life is the development of spirituality and consciousness of citizens, which allow to provide the necessary intellectual potential to fulfill its requirements (Zhuk, 2015: 26).

The Ukrainian researcher A. Kalinina calls access to comprehensive and alternative information, critical analysis of everything and everything as the key to overcoming totalitarian tendencies at the personal level (Kalinina, 2014: 286). Nevertheless, the majority of Ukrainian society, according to various sociological data, having all potential opportunities to access an infinite mass of information obtains information from television. Moreover, most of the TV channels belong to the oligarchs, the smaller ones belong to the state, and public broadcasting is a very small part. As a rule, Ukrainians have unlimited trust in their favorite TV channel, not at all checking the information provided by other sources. This creates a fertile ground for neo-totalitarian tendencies in individual and collective consciousness and contributes to the establishment of imitative democracy (Kalinina, 2014: 286).

Thus, a large number of newly-formed states and, in general, post-Soviet society, were not at all levels prepared for real democratic change. They came to power from the Soviet Union, who, for the most part, in declaring democratic principles, sought to gain more power and influence rather than build a democratic state and civil society.

The result of the formation and functioning of modern totalitarian democracies is information overload, populism, social infantilism and indifference, legal nihilism and absenteeism.

Problems with democracy in the world are leading to increased populism. Right-wing populists have already won seats in the parliaments of France, the Netherlands, Germany, Austria, and Italy. The same political forces continue to strengthen positions in Hungary and Poland, where laws have been passed restricting the activities of non-governmental organizations. The rise of populism can also be observed in Ukraine, in which democratic transit is still far from a stable and irreversible state.

Because of the popularization of the idea of democracy by populist politicians and dictators of different styles, many citizens from different countries have a dangerous apathy for the principles of a free democratic society. And those who advocate liberal democracy are subject to various attacks and harassment. Moreover, certain politicians (for example, Orbán in Hungary) even choose the main leitmotif of their election campaign to fight against philanthropists, liberals and civic activists who advocate for the ideas of pluralism, the rule of law, strong civil society structures, and important civil society structures areas such as politics, economics and culture.

At the beginning of the $21^{\text {st }}$ century, a new pan-European tendency is emerging - the emergence of populist "third forces" seeking to occupy a niche in political life and sufficiently fighting for power and influence with traditional liberal-democratic political forces.

Thus, populism is one of the greatest threats to democracy both in the world and in Ukraine. The vast majority of populist movements in the world are anti-elitist in nature and imply an organic polarizing ideology that opposes the majority minority and leads to criticism of 
representative institutions and a vivid leader capable of turning popular discontent and protest into a power mobilization strategy. In the post-socialist space of Eastern Europe, populism may also be perceived as an eclectic fuzzy ideology that contains predominantly "right" ideological elements but is also capable of compiling them with "left" rhetoric depending on the socioeconomic and political context of the individual country. From populism, which is perceived as ideology, in turn follows a certain form of political strategy. The ambiguity and plasticity of the ideological core of the populist movements of Eastern Europe enables them to combine populist rhetoric with many classical ideologies such as nationalism (Martinelli, 2016: 15).

The researchers distinguish two main types of populism: 1) protest (social) and 2) identity (nationalist). Protest populism is a critique of the elites, combined with the glorification of a people who are understood as "ordinary people", "ordinary citizens." This kind of populism means "hyper-democracy", a call for direct democracy and a denial of ordinary democratic procedures. Identity populism, like protest populism, is directed against the elites, against a democratic state as an institution, but the focus is on protest against "foreign", "foreigners." The elites are condemned primarily because they are not national, but detached from the people, cosmopolitan. Also there are right and left populism. The fundamental difference between them is the image of the enemy. The enemy of right-wing populism is the "emigrant", "alien", and "other." The enemy of left populism is the "world of capital", "oligarchy", and "banks."However, both of them agree on one thing: officials have moved away from the people and do not represent the interests of society.

In today's Europe, political parties that harness the potential of populist identity have the greatest political success. Not all citizens are able to appreciate the fundamental values of liberal democracy - freedom of personality, pluralism of lifestyle and belief, mutual tolerance and willingness to compromise, respect for the democratic order. As soon as the crisis occurs, many citizens are happy to give their fate and freedom to the right populists. Today, the main cause of the electoral success of right-wing populists is the migration crisis and the flourishing of racial and ethnic xenophobia in these societies. European populists rely on the politicization of ethnicity and cultural racism.

Analyzing the situation with liberal democracy in Eastern Europe, it cannot be mention the eminent political scientist Samuel Huntington, who, while exploring the waves of democratization, referred to the backward waves (a fallback to authoritarianism) - the replacement of democratic systems with historically new forms of authoritarian rule. He wrote about the possibility of a third feedback wave because of two conditions. First, the demonstration of the continued viability of undemocratic rules by the new authoritarian powerful countries. Secondly, the decline of the United States as a world of democracy, a manifestation in this country of political stagnation, inefficiency of the economy and social chaos. It is likely that the time of the third rollback has begun. China and Russia are demonstrating the viability of their undemocratic regimes, and the US is losing its leadership and demonstrating revisionist policies on the important foundations of liberal democracy, foreign policy adventurism and extreme domestic polarization.

The situation in Eastern Europe has become an echo of this state of affairs, which is of great concern. The pioneers in the fight against liberal democracy in this region were Hungary and Poland, which saw a convincing electoral perspective in conservative populism, demonization of liberals and their global values, attacks on minorities, the search for historical justice, the fight against foreign powers, eroding the democratic system of checks and balances. The Czech Republic and Romania are likely to follow this path. Politicians in all these countries, as a rule, 
do not oppose a democratic political regime, and do not campaign openly for authoritarian rule; they build their policies on the basis of rigid criticism of liberal methods and principles of social organization. Their main weapon is populism as a political ideology, which seems to be defending the interests of the common people as opposed to the interests of the various elites, in our case it is a matter of the so-called the "Western capitalists." In fact, it is about forming an anti-liberal democracy as an alternative to liberalism, which can become a long-term political trend in Eastern Europe.

The question is, why in Eastern Europe such a fierce struggle against liberalism and the values of an open society? According to the head of the Center for Liberal Strategies (Sofia) Ivan Krastev, the answer to this question is to be found in the specific nature of the revolutions of 1989, when states liberated from Soviet oppression expressed the idea of normality to lead a normal life already available to Western Europeans (Krastev, 2018). This process was accompanied by mass emigration of the most educated and liberal citizens from these countries to their western neighbors, which led to serious demographic problems and crisis of identity in Eastern Europe. The massive departure of the "liberals" changed the structure of the electoral field of these countries, liberalism lost its internal resistance and human driving force. The image of liberalism in Eastern Europe has become the EU and the US, and the weakening of their influence has been the impetus for a populist-nationalist anti-liberal revolution, the effects of which we are all now acutely aware.

At the same time, those who left have increased their social status, because they immediately got a normal life, and those who remained in their unreformed homeland began to feel like the losers who are trapped behind by the advancement of social life. That is, the East Europeans were given the inferiority complex, which became a fertile ground for populism.

East European populism is growing. The right-wing Polish populist party has won a parliamentary majority and now retains leadership in polls, and the right-wing populist Fidesz Party has won two consecutive parliamentary elections in Hungary. The success of populism in this region cannot be explained by economic problems alone. Indeed, Orban came to power in 2010 after the Hungarian economy slumped by $6.6 \%$ in the crisis year of 2009 , but the Czech Republic, Slovakia and Poland have fallen out of this logic. The Czech Republic has the lowest unemployment rate in Europe, but this did not prevent its citizens from voting in the parliamentary elections for populist parties. Poland from 2007 to 2017 showed the fastest economic growth in Europe, but the PIS populists has won on the elections. The roots of populism and the anti-liberal movement in Eastern Europe lie in the face of demographic change and problems that weaken exemplary ones from the perspective of the liberaldemocratic values of the United States and the "old Europe."

Common to all these populist movements is the desire to change the rules of the game and move away from liberal-democratic governance. Therefore, after coming to power in Hungary, the Fidesz Party used its constitutional majority and actually changed the electoral system to its advantage. It is also worth noting the increase in corruption in this country with the rise of populists to power. The Polish government also sought to change the rules of the game, the object of its attack was the system of checks and balances, which they tried to dismantle through changes in the constitutional court. Unlike the Hungarian government, the corruption situation in Poland is much better. They are less focused on controlling the economy and focus on moral issues, seeking to re-educate their citizens and change their assessment of history.

Despite differences in certain approaches, one can note the emergence of an anti-liberal consensus, the tools of which are nationalism and xenophobia. Of great concern is the support 
for this movement by young people, for whom totalitarianism is so remote and unfamiliar that they are willing to abandon liberal-democratic values in favor of an authoritarian government that seems to be experiencing for them, rather than for the elitist world groups that "plays" with all liberal groups, puppets, cashing in on ordinary people. The majority's rights are at the heart of this consensus. They seek to enhance cultural and political polarization, to form the image of the enemy on the basis of the conspiracy theory of a bunch of rich people who want to make a living at the expense of most citizens in different countries of the world. This approach is based on the allegations of Fidesz representatives that Brussels, with the help of billionaire George Soros, was secretly planning to flood the country with migrants.

Both Fidesz and PiS represent themselves as the true voice of a nation that fights against internal and external enemies. Moreover, they actively introduce the concept of the right citizen - a true Pole or Hungarian. They view all others as untrue people who interfere with the will of the people. To them, all dissenters are the wiles of "conspirators" who seek to continue the exploitation of their state.

A unifying moment for Eastern European populists is the attitude towards the European Union, which, on the one hand, is used as one of the images of evil and, on the other, does not neglect to use its financial resources. Economic growth, both in Poland and Hungary, is largely due to EU funds. The East Europeans' annoyance with Brussels can be explained by their desire for self-affirmation and their efforts to overcome a certain set of inferiority. The countries of Eastern Europe aspire to become full members of the European club, and not just objects of instruction from the developed West. While they have viewed Brussels as a benevolent friend since the beginning of the European integration process, today they are perceived by EU commissioners as largely interfering with internal sovereignty. In general, foreign power is a historical trauma for most Eastern European countries.

The trigger of the rise of populism in Eastern Europe was the migration crisis of 20152016. The citizens of these countries fear migrants and refugees. According to sociological surveys, more than $50 \%$ of Poles and almost $70 \%$ of Hungarians believe that their country's borders should be completely closed to refugees. The reason for this attitude towards migrants is that the region of Eastern Europe consists mainly of small aging, ethnically homogeneous societies. Cultural and ethnic diversity, which is the norm for Western European countries, is perceived as an existential threat in Eastern Europe. On this basis, the formation of the anti-liberal movement is taking place in this region. Thus, the sources of Eastern European populism are both the emigration of liberally minded citizens to Western Europe and the fear of global immigration from the Middle East.

Geopolitical instability in the region has also become a major factor in the anti-liberal revolution in Eastern Europe. While the EU and the US played a major role in consolidating liberal Eastern European democracies, these countries felt completely safe. However, revisions to US allies, the debt crisis, refugees and Brexit in the EU, as well as the revisionist policies of the Russian Federation, have forced these countries to re-evaluate their geopolitical challenges and threats. At the same time, the Russian factor (a combination of authoritarianism with antiliberal ideology) for some, such as Hungary, became an example for imitation, and for others, such as Poland, it became an additional incentive to vote for anti-liberal forces, which would seem to be the only ones able to really defend the country, because the liberal "Old" Europe has failed to respond adequately to Putin's violations of the world order.

Thus, anti-liberal populism is on the rise across the European continent, but it is particularly acute in Eastern Europe. Eastern European populism has deep historical roots and is likely 
to be a long-term factor in the situation in the region. The main reasons for this are: 1) the emigration of liberal-minded citizens from the region to advanced democracies in search of a normal life; 2) reducing the role of the United States as a liberal-democratic outpost; 3) the migration crisis in the EU. In fact, anti-liberal democracy is a new kind of authoritarianism, the main danger of which is that it was born in democracy itself, and its main tenet is that the power of the majority need not to be restricted, because it comes from the people and is realized for them, and all the liberal restriction is an attempt of external influence and control. The destruction of the liberal system of checks and balances is still the main result of an antiliberal democracy in Eastern Europe. Anti-liberal democracy does not bypass Ukraine, though its manifestations in our country have certain specific characteristics.

In Eastern Europe, populism is predominantly based on collectivist and ethno-nationalist (ethnically exclusive) traditions against the background of recent history. Thus, it has a relatively modern historical origin and is rather in the "right" version. The coming of the rightwing populists to power in Hungary in 2010 and Poland in 2015, and their electoral successes in other countries of Eastern Europe during the 2000s, cannot be regarded as an unexpected sensation. In fact, the neo-populist wave in the post-socialist states was the result of a total fatigue from democracy. Among the common genetic reasons behind the great success of populists in the post-socialist space of Eastern Europe are:

a) the blurring of value orientations in transitional societies, a marked disappointment in the socio-economic results of democratization by maintaining a qualitative development gap in comparison with Western European countries;

b) intransigence of party-political confrontation, high polarization of political forces in the ideological spectrum on the "right-left" scale;

c) the absence of a systematic policy course on the formation of a collective civic identity in the destruction of a system of rational social discourse and constructive dialogue as a result of the fierce confrontation between the "right" and "left" in the political field of post-socialist states;

d) instability of socio-stratification structure and regime of property relations in transitive societies, oligarchization of political and economic elite;

e) the managerial inability of moderate reformist political forces to respond adaptively to emerging challenges and to hold the electorate's political preferences in a crisis;

f) imperfection of the institutional design of state power and the system of checks and balances set out in the Constitution of most Eastern European countries;

g) European regional crises (the debt crisis in the Eurozone and the migration crisis in the EU) have greatly contributed to the growth of support for radical right-wing populists in Eastern Europe.

It should be noted that all populist movements in post-socialist countries are characterized by a certain set of general features:

First, populism in Eastern Europe does not boil down to political extremism, which seeks to completely dismantle liberal democracies, populists aiming at modifying existing representative democracy into a plebiscite one.

Second, populist movements in the post-socialist space are ideologically differentiated into "rigid" ("Jobbik" in Hungary, "Attack" in Bulgaria, "Camp of Greater Poland" and others) and "moderate" ("Fidesz" in Hungary, "PiS" in Poland, GERB in Bulgaria and others), although the real boundary between them is plastic and flexible. 
Third, populist ideological platforms that mobilize voters in Eastern Europe are increasingly based on identity politics. As mainstream centrist parties increasingly lose their attractiveness, appeal to nationalism and identity politics becomes more and more attractive to the public.

Fourth, populism in Eastern European countries is not a specific phenomenon of "postaccession" to the EU, despite the claim that the rise of populism is driven by high expectations of EU membership and fatigue from long-term austerity measures, since populist (mainly) right parties began to form in post-socialist countries from the late 1990s.

Fifth, the populist wave in Eastern Europe is not a temporary departure from a certain vision of "normality." In the political process, long-term changes are taking place in the post-socialist space that contribute to the spread of populism: politics are becoming more personalized and focused on social networks and the media. Populist parties and movements that pay particular attention to the communication system and the personalities of their leaders are much better suited to the new environment than mainstream parties, which account for their growing electoral victories.

It is important to emphasize that the main real goal of the vast majority of populist movements is the permanent retention of power in order to maximize their political and economic preferences and to convert the acquired power positions into resource capabilities, which requires a leveling of the existing system of democratic control. Based on the examination of the two cases of Hungary and Poland, in which the populist parties Fidesz and PiS succeeded in winning the elections, it is possible to trace the stages of deconstruction of democratic political institutions by the populists who came to power:

1. Restricting media freedom in order to gain control over the public agenda. In Hungary, this was reflected in the creation of a National Communication Office, which controls the state media, and in the forced depoliticisation (threats of sanctions and advertising taxes) of the private media; in Poland — through the nationalization of public service broadcasters and their editorial policy as a result of legislative amendments.

2. Reformatting the system of separation of powers to remove existing institutional constraints in the political field. In both states, this was primarily due to a change in the procedure for the formation of the Constitutional Court in order to subordinate the judiciary to the executive.

3. Amendments to the electoral legislation that ensure guaranteed success in the next electoral cycles. It is noteworthy that such anti-democratic measures are carried out by populists in Poland under the slogan "the will of the people is more important than the constitution or laws", despite the fact that the term "people" acquires a very restrictive definition: it is no longer the only nation but only the electorate and supporters of the ruling party (Sztompka, 2016: 89). After all, the result of the populist policy of politics is the formation of illiberal democracy, which in Hungary, according to B. Magyar, took the form of a post-communist mafia state, which arose from the decay of a one-party dictatorship of a privatized parasitic state, an economic political entity power (Magyar, 2016: 6).

However, it should be noted that the same factors that give far-right populists the opportunity to achieve major electoral success today might soon turn against them, since the "third way" and "simple solutions" to the complex problems facing the European countries they offer are wholly illusory. They are not capable of practically satisfying electoral "demand", but almost 
inevitably their activity is capable of generating new problems and conflicts. Right-wing populism is undoubtedly dangerous for democracy, especially in Eastern Europe, as it appeals to the uncontrolled mobilization of the masses, not in the name of creation but in the name of destruction. Using utopias and mass illusions, populism emphasizes the existing distinction between a speculative democratic ideal and an imperfect democracy. Populists put the agenda on the agenda with really pressing issues, but they answered incorrectly.

Populism can destroy democracy as it seeks to centralize power, weaken checks and balances, strengthen executive power, neglect political opposition, and transform the election into a plebiscite that serves the interests of the leader. The core of populism is the people, not the citizen. Populist politics is far from pluralism, dissent, minority views.

The neo-populist wave is a serious threat both to national democracies in post-socialist states and to the functioning of the EU, whose external control is a major deterrent to pushing populist Eastern European regimes into consolidated authoritarianism.

\section{Conclusions}

The $21^{\text {st }}$ century is a time for the flowering of totalitarian democracy. It can be used both in the positive sense - the transition from an overtly totalitarian or authoritarian regime to a liberal-democratic one, and contains the characteristic features of a direct representative democracy, and in a negative one - it is conditioned by the transition from a liberal democracy to an imitative one, or by increasing controllability in the already existing pseudo chemistry.

Thus, forms of totalitarianism adapt to the conditions of the present and acquire new improved and modified features. Therefore, it is critically important to be able to recognize the various aspects of any form of totalitarian rule and to devise effective ways of preventing the imitation of democratic regimes.

The two biggest problems of liberal democracy are, first, the strengthening and establishment of authoritarian regimes that promise prosperity, progress, stability and prosperity without democratic values. Moreover, they are trying to show democracy as a brake on the development and achievement of the community, and they are throwing all their forces at the fight against it, mobilizing the masses, convincing them that the whole problem lies in democracy, not in inefficient governance, corruption, clientelism, etc. Although their real purpose is to secure the continued restoration of power, the monopolization of resources, and the ability, at their own discretion, to redistribute public wealth for its own benefit. Secondly, the challenge for liberal democracy is the wave of legal populism, nationalist and xenophobic movements in free and partially free countries, which covers country after country.

Liberal democracy is being deconstructed by populist political forces in many countries. Developed democracies of the world are no exception. The wave of anti-liberal movements is gaining momentum in the United States, Germany, France and Italy. These movements are most threatening in Eastern European countries - Hungary and Poland. Populists in these countries, by appealing to conspiracy theory, seek to blame all the troubles of liberals, who seem to be wringer the citizens, forcing difficult reforms that ultimately do not bring people a normal life and social wellbeing. At the same time, the nature of citizens' relations with the traditional press is changing qualitatively: the mainstream media is increasingly losing out to social media, which, along with conflicting discourse, political cynicism, fakes and soft propaganda, is becoming a populist information weapon.

What to do to protect democracy? 
First, clear and correct concepts must be employed, in particular to distinguish a referendum from a plebiscite that has nothing to do with democratic voting or direct democracy. Democratic elected governments must engage in a real and serious dialogue with citizens in the inter-election period, otherwise the gap between the people and their representatives will widen geometrically, making full use of populists. Direct democracy and, especially, the instrument of popular legislative initiative can overcome this gap.

Secondly, direct democracy must be developed first and foremost with a digital focus, including both tools for organizing mass political actions and new opportunities for financing political projects, for example through crowdfunding. Democratic governments should go to their citizens and ask about their needs.

Third, the creation of online platforms that, on the one hand, act as an educational space for political democracy and demonstrate best practices of democratic government, on the other hand, serve as a platform for uniting Liberal Democrats, promoting values of an open society and consolidating efforts in the fight with populists. We need to create new spaces for discussion, the so-called Massive Online Deliberation Platforms, which will allow people to communicate with each other in a different way than what is currently happening on social networks. These new spaces should be in pre-moderation mode, there should be clear rules, and increasingly sophisticated systems built on artificial intelligence technology should identify and cut off the so-called "trolls", paid disseminators who seek to turn any civilized debate into bazaar. Such "discussion platforms", by the way, open to high-quality media, too, should operate on the basis of special algorithms, only they will be focused not on enhancing emotions and not on relaying hatred, but on supporting rational arguments.

In order to protect the values of democracy and effectively confront today's information and political challenges, we also need to:

a) mobilize civil society to support democratic values and institutions through the creation of mass-based online debate platforms with appropriate moderation and discussion rules;

b) restore confidence in electoral democracy, by improving electoral legislation in the electoral system and increasing accountability for bribery;

c) strengthen the rationalization and institutionalization of the political process;

d) improving the quality of media work, including the implementation of a more responsible information policy;

e) civic education for young people, for the sake of inculcating values of an open society, forming critical thinking and generating a request for ideological parties with institutional fuses that would hold its representatives within the values within their ideological vector;

f) involving citizens in political decision-making; build inclusive political institutions and the economy in parallel;

g) to conduct factcheck of populist statements based on facts and reality;

h) return to national dialogue and constitutionalism;

i) to carry out political isolation of populists by forming large centrist coalitions in parliament; involve "new faces" in centrist parties. 


\section{References}

Furman, Dmitry (2007) General and Special in the Political Development of the Post-Soviet States. Ways of Russian Post-Communism: Essays. Ed. M. Lipman and A. Ryabova. Moscow Carnegie Center. Publishing House of R. Elinin: 234-272

Furman, Dmitry (2007) Problem 2008: General and Special in the Processes of Transition of the Post-Soviet States. Full Transcript of the Lecture dated September 27, 2007. Полит.py. http://polit.ru/article/2007/10/19/furman/

Engdahl, W.F. (2010) The full range of dominance. Totalitarian democracy in the New World Order. St. Petersburg.

Kalinina, A. (2014) From classical totalitarianism to totalitarian democracy. Current issues of politics. Vol. 52: $281-288$ p.

Krastev, I. (2018) Eastern Europe's Illiberal Revolution: The Long Road to Democratic Decline. Foreign Affairs. https://www.foreignaffairs.com/articles/hungary/2018-04-16/ eastern-europes-illiberal-revolution

Magyar, B. (2016) The Anatomy of a Post-Communist Mafia State: The Case of Hungary. Moscow: New Literary Review.

Martinelli, A. (2016) Populism and the Crisis of Representative Democracy.Populism on the Rise: Democracies Under Challenge? Edited by Alberto Martinelli. Milano: EdizioniEpok. ISPI: 13-32.

Pribylovsky, V. (2005) What is "controlled democracy": concept, history. Russian experience. http://www.sova-center.ru/democracy/publications/2005/03/d3986/

Sztompka, P. (2016) The "Demand Side" of Populism: The Case of Poland. Populism on the Rise: Democracies Under Challenge? Edited by Alberto Martinelli. Milano: EdizioniEpok. ISPI: 73-91.

Talmon, J.L. (1961) The origins of totalitarian democracy. Mercury Books, 1961.

Talmon, J.L. (1993) Origins of totalitarian democracy. Totalitarianism: what it is (studies of foreign political scientists): collection of articles, reviews, essays, translations. Two parts. Moscow. - Part 1: 191-214

Zhuk, N.A. (2015) Imitation democracy as the dominant political regime in the modern world states. Bulletin of the V.N. Karazin National University of Kharkiv. Series "Law". Vol. 20: $25-28$. 